\title{
Recurrent seizure activity after epidural morphine in a post-partum woman
}

\author{
[Activité épileptique récurrente après une anesthésie péridurale avec morphine \\ chez une femme en postpartum]
}

Chih-Jen Shih MD, ${ }^{*}$ Anthony G. Doufas MD PhD, $†$ Hsu-Chu Chang MD, ${ }^{*}$ Chun-Ming Lin MD*

Purpose: We report on a primiparous woman who suffered recurrent seizure activity after repeated small doses of epidural morphine to highlight the neuroexcitation potential of neuraxial opioids in the epileptic patient.

Clinical features: Seizure activities as a complication of opioid administration have been reported in laboratory animals and humans. We report the case of a 30-yr-old primiparous woman with a history of epilepsy under carbamazepine treatment, who had epidural anesthesia for elective Cesarean section at 38 weeks gestation. Postoperatively, $1.5 \mathrm{mg}$ of morphine were administered epidurally for pain control. Three hours later the patient suffered from clonic movements of the right arm without loss of consciousness. One day later, she again received I mg of epidural morphine twice at a I2-hr interval and similar seizure episodes recurred eight hours after each dose. A relation between the administration of morphine and seizure activity was suspected and the use of opioids for pain control was stopped. The patient was discharged on the fifth postoperative day and, more than one year after the last episode, she remains free of any seizure activity.

Conclusion: Our report indicates that even a remote history of epilepsy carries a pro-convulsant potential in the peripartum period, even following the administration of small doses of epidural morphine.

Objectif : Présenter une primipare qui a souffert d'épilepsie récurrente, après avoir reçu de petites doses répétées de morphine péridurale, pour souligner le potentiel neuroexcitateur des opioïdes neuraxiaux chez l'épileptique.

Éléments cliniques : Les crises d'épilepsie comme complication de l'administration d'opioïde ont été constatées chez les animaux de laboratoire et chez les humains. Nous présentons le cas d'une primipare de 30 ans, épileptique traitée avec de la carbamazépine, qui a reçu une anesthésie péridurale pour une césarienne réglée à 38 semaines de grossesse. Après l'opération, elle a reçu 1,5 mg de morphine pour l'analgésie péridurale. Trois heures plus tard, elle a souffert de mouvements cloniques du bras droit sans perte de conscience. Le lendemain, elle a reçu deux doses de $1 \mathrm{mg}$ de morphine péridurale, à $12 \mathrm{~h}$ d'intervalle et des crises similaires sont survenues huit heures après chaque dose. Une relation entre la morphine et l'activité épileptique a été présumée et l'administration de morphine a été stoppée. La patiente a quitté l'hôpital au cinquième jour postopératoire et n'a subi aucune crise plus d'un an après le dernier épisode.

Conclusion : Notre article indique que même une histoire ancienne d'épilepsie comporte un potentiel pro-convulsivant en période postpartum, après l'administration péridurale de petites doses de morphine.

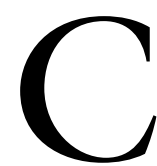

ENTRAL nervous system excitation ${ }^{1}$ is among the less common side effects of epidural opioids. Seizure activity as a complication of opioid administration has been reported in laboratory animals, ${ }^{2}$ adult humans ${ }^{1,3,4}$ and neonates. ${ }^{5}$ Myoclonic activity has been described after high-dose intrathecal, ${ }^{6}$ epidural ${ }^{1,4}$ or $i v^{4}$ opioids. However, only one report in the literature describes the development of seizures after epidural morphine in a patient with a known history of epilepsy. ${ }^{7}$ We report the case of a primiparous woman with a history of simple partial seizure with secondary generalization, who experienced recurrence of motor seizure activity after epidural administration of a small dose of morphine for postoperative pain control.

\section{Case report}

After obtaining consent from the patient according to patient health information guidelines of the Chang

From the Department of Anesthesiology, Chang Gung Memorial Hospital, * Tao Yuan, Taiwan; and the Department of Anesthesiology and Perioperative Medicine and OUTCOMES RESEARCH ${ }^{\mathrm{TM}}$ Institute, $\dagger$ University of Louisville, Kentucky, USA.

Address correspondence to: Dr. Chun-Ming Lin, Department of Anesthesiology, Chang Gung Memorial Hospital, 5, Fu-Hsing St.,

Tao Yuan, Taiwan. E-mail: sam2498@adm.cgmh.org.tw. Reprints will not be available by the authors.

Accepted for publication January 4, 2005.

Revision accepted March 4, 2005. 
Gung Memorial Hospital, we describe a 30-yr-old primiparous woman who presented for elective Cesarean section at 38 weeks gestation. She was generally healthy except for a remote history of a seizure disorder which consisted of three isolated episodes at the age of 17. She denied a history of head trauma or any developmental problems. The first seizure attack was associated with tonic-clonic convulsions accompanied by loss of consciousness. Computed tomography did not reveal any intracerebral pathology, while electroencephalography (EEG) revealed epileptic activity over the left temporal lobe. A diagnosis of simple partial seizure with secondary generalization was made, and the patient was treated with carbamazepine, 200 $\mathrm{mg}$ po daily. Shortly after treatment initiation, the seizure activity recurred twice in the form of clonic convulsions of the right arm and carbamazepine was increased to $200 \mathrm{mg}$ po bid. The patient was followed regularly in our neurology clinic and she remained seizure-free on the higher dose of carbamazepine.

Epidural anesthesia was accomplished with an 18-G Tuohy needle via the L4 $\mathbf{- 5}$ intervertebral space, using a midline, loss-of-resistance approach with $2 \mathrm{~mL}$ air. A $3-\mathrm{mL}$ test dose of lidocaine was given before the lidocaine bolus and a total bolus of $20 \mathrm{~mL} 2 \%$ lidocaine with l:200,000 epinephrine and $50 \mu \mathrm{g}$ fentanyl was administered through the needle and an epidural catheter was placed atraumatically. The dermatomal level achieved was T6 $20 \mathrm{~min}$ after induction of epidural anesthesia. The operation was completed without any complications and the newborn was extracted in good health. The patient was comfortable upon arrival in the postanesthesia care unit and $1.5 \mathrm{mg}$ of morphine sulfate diluted in $10 \mathrm{~mL}$ normal saline were administered epidurally for pain control.

After resolution of the sensory block to Ll level, the patient was discharged to the ward. Two hours later and three hours after the morphine administration, she suffered from involuntary movements of the right arm without loss of consciousness. At the beginning, we did not know the reason why she had such abnormal movements. We immediately checked electrolytes, blood glucose, magnesium, and calcium levels which were all within their normal ranges. The patient described her symptoms as being similar to those she had experienced during the seizure attacks at the age of 17. Since she had used carbamazepine to achieve succesful control her epilepsy, we gave her 200 $\mathrm{mg}$ of carbamazepine po. The seizure activity lasted for approximately one hour with several brief seizure-free intervals, and it gradually resolved after the $200 \mathrm{mg}$ dose of carbamazepine. One day later, she again received epidurally $\mathrm{l} \mathrm{mg}$ of morphine (2nd and $3 \mathrm{rd}$ doses) within a 12-hr interval, and a similar seizure episode occurred eight hours after each dose. Because the seizures occurred at the same relative time after morphine injection, a relation between the administration of morphine and the seizure activity was suspected and the use of opioids for pain control was stopped. No more seizure activity occurred after disconnection of the intermittent administration of epidural morphine. The normal carbamazepine regimen of $200 \mathrm{mg}$ po bid was continued throughout the perioperative period. The patient was discharged on the fifth postoperative day. After discharge, an EEG evaluation showed no change from the previous examination. The patient was followed by the neurology services and she remained free of any seizure over a one-year follow-up period.

\section{Discussion}

The exact mechanism of opioid-induced neuroexcitation remains to be elucidated. Direct opioid and non-opioid receptor-mediated excitatory, as well as inhibitory systems have been implicated. Active metabolites and drug preservatives have been also incriminated, as well as a pro-convulsant effect of opioids in association with metabolic and other toxic factors.

Animal models ${ }^{8,9}$ show that opioid-induced seizures may involve multiple opioid receptor-mediated mechanisms, while a stereospecific kappa-receptor mechanism is directly implicated. ${ }^{8}$ Nonetheless, evidence that naloxone was unable to completely reverse opioid-induced myoclonous ${ }^{2}$ disputes opioid receptors as mediators of neuroexcitation. Indirect opioidinduced effects on different excitatory and inhibitory systems at various central nervous system levels may explain this discrepancy. ${ }^{2,10}$ Thus, $\mathrm{N}$-methyl-D-aspartate mediated excitation, ${ }^{11}$ as well as gammaaminobutyric acid (GABA)-mediated inhibition ${ }^{12}$ have been also a factor in opioid-induced neuroexcitation, while morphine-induced glycine and GABA antagonism were associated with paroxysmal depolarizations of spinal cord neurons in vitro. ${ }^{10}$

Active metabolites, ${ }^{13}$ as well as preservatives ${ }^{3}$ of different opioid agents have been implicated in causing generalized seizures in humans after systemic administration of high dose opioids, although the parent compounds have their own neuroexcitatory potential.

Neuroexcitation usually occurs after large doses of intrathecal, ${ }^{6}$ epidural $^{14}$ or $i v^{4}$ opioids. None of the patients described in the literature had a history of seizure disorder and myoclonic activity was never observed with an epidural dose of morphine lower than $12 \mathrm{mg} \cdot \mathrm{hr}^{-1} .{ }^{4}$ Nonetheless, tonic-clonic activity has been reported in an epileptic woman who had 
elective Cesarean section, six hours after the epidural administration of $3 \mathrm{mg}$ of morphine. ${ }^{7}$

Human studies have shown that central effects of epidurally administered morphine, like delayed ventilatory depression ${ }^{14}$ and nausea, ${ }^{15}$ are mostly due to rostral spread of the drug through the cerebrospinal fluid and have an onset time between four and nine hours. In our case, myoclonic activity occurred three and eight hours after epidural administration of 1.5 and $1 \mathrm{mg}$ of morphine, respectively. Thus, the time course of the seizure effect supports a central mechanism of action through the cephalad spread of morphine.

Despite the fact that systemic administration of low doses of morphine has a rather anticonvulsant effect, neuroexcitation can also occur in a pro-convulsant environment. ${ }^{16,17}$ The endogenous opioid system has been implicated in exerting a continuous anti-convulsant action. ${ }^{16,18}$ A step rise in plasma endogenous opioids during late pregnancy and parturition ${ }^{19}$ might be responsible for decreased seizure susceptibility. ${ }^{16}$ However, the acute resolution of this situation in the post-partum period could also have a pro-convulsant "opioid withdrawal" effect, ${ }^{20}$ especially on the grounds of seizure disorder.

Our patient, and that described by Borgeat et al., ${ }^{7}$ share a history of epilepsy and recent pregnancy. An epileptic pathology, even with the form of a dormant focus, might have interacted with the condition of pregnancy to produce a pro-convulsant environment for the seizure-inducing effect of small doses of morphine. The time course and the pattern of convulsive activity, as well as the fact that it promptly resolved with carbamazepine support the case of seizure recurrence due to epidural morphine administration.

Our report indicates that a remote history of epilepsy carries a pro-convulsant potential in the peripartum period, even following the administration of small doses of epidural morphine.

\section{References}

1 Jayawardena B, Hill DJ. Myoclonic spasms after epidural diamorphine infusion. Anaesthesia 1991; 46: 473-4.

2 Shohami E, Evron S. Intrathecal morphine induces myoclonic seizures in the rat. Acta Pharmacol Toxicol (Copenh) 1985; 56: 50-4.

3 Gregory RE, Grossman S, Sheidler VR. Grand mal seizures associated with high-dose intravenous morphine infusions: incidence and possible etiology. Pain 1992; 51: 255-8.

4 Rozan JP, Kahn CH, Warfield CA. Epidural and intravenous opioid-induced neuroexcitation. Anesthesiology 1995; 83: 860-3.
5 Young GB, da Silva OP. Effects of morphine on the electroencephalograms of neonates: a prospective, observational study. Clin Neurophysiol 2000; 111: 1955-60.

6 De Conno F, Caraceni A, Martini C, Spoldi E, Salvetti $M$, Ventafridda $V$. Hyperalgesia and myoclonus with intrathecal infusion of high-dose morphine. Pain 1991; 47: 337-9.

7 Borgeat A, Biollaz J, Depierraz B, Neff R. Grand mal seizure after extradural morphine analgesia. $\mathrm{Br} \mathrm{J}$ Anaesth 1988; 60: 733-5.

8 Bansinath $M$, Ramabadran K, Turndorf H, Shukla $V K$. Intracerebroventricular administration of kappaagonists induces convulsions in mice. Brain Res Bull 1991; 27: 75-9.

9 Crain SM, Shen KF. Opioids can evoke direct receptormediated excitatory effects on sensory neurons. Trends Pharmacol Sci 1990; 11: 77-81.

10 Werz MA, Macdonald RL. Opiate alkaloids antagonize postsynaptic glycine and GABA responses: correlation with convulsant action. Brain Res 1982; 236: 107-19.

11 Chen L, Huang LY. Sustained potentiation of NMDA receptor-mediated glutamate responses through activation of protein kinase C by a mu opioid. Neuron 1991; 7: 319-26.

12 Foote F, Gale K. Morphine potentiates seizures induced by GABA antagonists and attenuates seizures induced by electroshock in the rat. Eur J Pharmacol 1983; 95: 259-64.

13 Yaksh TL, Harty GJ. Pharmacology of the allodynia in rats evoked by high dose intrathecal morphine. J Pharmacol Exp Ther 1988; 244: 501-7.

14 Knill RL, Clement JL, Thompson WR. Epidural morphine causes delayed and prolonged ventilatory depression. Can Anaesth Soc J 1981; 28: 537-43.

15 Bromage PR, Camporesi EM, Durant PA, Nielsen CH. Nonrespiratory side effects of epidural morphine. Anesth Analg 1982; 61: 490-5.

16 Frenk $H$. Pro- and anticonvulsant actions of morphine and the endogenous opioids: involvement and interactions of multiple opiate and non-opiate systems. Brain Res 1983; 287: 197-210.

17 Bertran F, Denise P, Letellier P. Nonconvulsive status epilepticus: the role of morphine and its antagonist. Neurophysiol Clin 2000; 30: 109-12.

18 Frost JJ, Mayberg HS, Fisher RS, et al. Mu-opiate receptors measured by positron emission tomography are increased in temporal lobe epilepsy. Ann Neurol 1988; 23: 231-7.

19 Abboud TK. Maternal and fetal beta endorphin: effects of pregnancy and labour. Arch Dis Child 1988; 63: 707-9.

20 Smolen A, Smolen TN, van de Kamp JL. The effect of naloxone administration on pregnancy-associated seizures. Life Sci 1986; 38: 1899-905. 